\title{
Sovereign Wealth Fund or State Capitalism: Nigeria's Search for a Stable Economic Order
}

\author{
G. S. Mmaduabuchi, OKEKE \\ Department of Political Science \\ University of Lagos \\ Nigeria
}

\begin{abstract}
For quite some time now, the Sovereign Wealth Fund (SWF) has become an issue in the front burner of Nigeria's national debate. The manner it was handled by the federal government became suspicious because there was serious disagreement among the stake holders, starting with the source of funding. But the whole idea of SWF in itself has remained controversial especially with regard to the problem it is meant to solve. The paper makes a contribution to this debate with an analysis of the extant literature and theoretical framework. It cites examples of successful experiences of the SWF and the circumstances that back up their results and suggests that Nigeria's search for a stable economic order does not lie in the SWF but more importantly to take care of all the necessary structural changes and erect a new political framework for a viable and durable economic development.
\end{abstract}

Keywords: Nigeria, Sovereign Wealth Fund, State Capitalism, Stable Economic Order.

\section{Introduction}

The entrance of Nigeria into the Sovereign Wealth Fund (SWF) Regime has generated a lot of comments from Nigerians and the Nigerian State development partners alike. The cynical criticisms of citizens, the resistance by the state Governors, as well as the embrace of the Western World, in particular the Breton Wood Institutions chunked out numerous literatures from respective divides. This is against the dilapidating state of infrastructure, biting poverty, endemic unemployment/underemployment; indeed the fledgling effort of the Nigerian state to meet with the United Nations Millennium Development Goals by 2015, which is the minimum standard expected of states in the $21^{\text {st }}$ century, so as to promote peace, stability, security and sustainable development; and enhance Global harmony. It has been stated that, "The principal objective of Nigeria's economic development has been to achieve stability, material prosperity, peace and social progress" (MDG Report, 2010: 8), hence the need to examine the timeliness or otherwise of the SWF in Nigeria.

This thesis questions the relevance of the SWF to the developmental needs of the country at this time. There are two major sides to Nigeria's SWF debate. While some believe in the wisdom of the Federal Government over the decision, others see it as not only undesirable, but a foolhardy venture meant to please the Western World as part of the Nation's conformity 
to the norms and values of globalization, as enthroned and supervised by the dominant power block in the international political and economic system.

\section{The Meaning of Sovereign Wealth Fund}

Sovereign Wealth Fund is a term coined by Rozanov as state owned re-financial vehicle which holds, manages or administers and invests public funds for the benefit of the state. (Kern, 2007). In other words, they are funds owned by governments or assets held by one government in another country's currency. This means that it is funded and managed separately outside the normal financial channel by monetary authorities. It can also be said to be funds invested for special purpose, arranged and managed by the general government. This differentiates the funds from the Central Banks that conventionally have exclusive hold on foreign reserves or state owned enterprises that own or acquire sector-relevant affiliates overseas, or public pension funds that overwhelmingly invest in domestic assets, but encompasses a variety of government investment vehicles, including stabilization funds and many pension funds.

\section{Understanding the Dynamics of Sovereign Wealth Fund}

The largest SWF by far is the fund of Abu Dhabi Investment with about 875 billion Dollars in assets as of February 2008, other countries with SWFs in excess of 100 billion US Dollars include China, Kuwait, Norway, Russia, Saudi Arabia and Singapore. Kuwait is said to have created the first modern fund in 1953, eight years before its independence (Drezner, 2008), but Hildebrand (2007) suggests that France's Caisse des Dépots et Consignations established in 1816 was the first fund in the modern sense. Hence, the Regime is not new to the industrialized World.

Startling these days are the scale and number of the SWF businesses and the potential and the perception of the potential influence these fund may have on investors at global scale with regard to their size, anticipated rate of growth, recent investment trend and countries of origin. There are 48 SWFs in the world owning assets nearing 3 trillion US Dollars (Sen, 2011) or between one and one and half percent of global asset markets (Drezner, 2008); with estimated growth rate at $24 \%$ over the past five years (Randolph, 2008), and are expected to reach about 10 trillion US Dollars in the next decade (IMF, 2008); with annual growth rate of 20\% (Jen, 2007; Setser and Ziemba, 2007, Randolph 2008) and may as well reach "four percent of global asset markets (Kern, 2007; Lyons 2007). Close to half of the top forty SWFs have been created since 2000, and eleven was established in 2009 alone (Sen, 2011). The source of the funds is primarily in the emerging markets as the prominent SWFs come from manufacturing and energy powerhouses in the developing world (Drezner, 2008), the greater Middle East and East Asian economies accounted for most of the world's SWFs. Within the top twenty in terms of size, seven are based in the greater Middle East and nine in the Pacific Rim economics. Saudi Arabia, Russia and China created large SWFs in the last two years. Among the biggest 20 SWFs, the average size is over 10 billion US Dollars, 
and these states are commodity exporters and countries running fiscal and trade surpluses. It is discovered that countries that export commodities have higher percentage of the SWFs. This appears to turn the world upside down - a paradigmatic change from a world in which private investors from wealthy industrialized countries used to invest around the globe, to one in which emerging market governments become major shareholders in Western countries -a new twist in the globalization story, as Kern, (2007) reflects trends in globalization and diversification. Truman (2007), in sharp contrast with industrialized countries argues that governments of non-industrialized countries are more actively involved in their countries international investments. The governments of India, China, Thailand, Indonesia, Korea and Malaysia controlled conservative estimate of at least 60 percent of their countries crossborder investments as of 2005. The comparative figure for the United States was 2.5 percent and Norway, with the largest SWF was 45 percent (IMF International Financial Statistics, 2008). What this translates to is that official inter-state investments varies the market-based global economy and financial system where vital decision making lies in the hands of private individuals involved in commercial activities.

The central motivation for the creation of SWFs by oil exporters are in three fold; to cushion the roller coaster of commodity boom and bust-converting assets extracted from the earth into a more liquid form; saving for the days when all the oil is extracted from below the ground, and attempting to forestall the Dutch disease of rapidly appreciating currency (Drezner, 2008). Hence, SWFs generally reflect the availability of excess government revenue and reserves in the relevant countries and the perceived need to manage these funds with a view to meeting the specific needs according to fund's objectives and smoothing income streams (Kern, 2007).

However, there are the challenges of building generally acceptable theoretical model for the appropriate timing to set up the SWF. While it is fashionable for emerging nations as a veritable alternative to stabilize their economies, but it has to be noted that recent financial crisis has seriously eroded the modest performances of the SWFs. Nevertheless, export engines like China are also using Sovereign Wealth Funds to keep their currencies fixed to dollar at a low par value. This is why in 2007 China had accumulated 1.8 Trillion US Dollars in assets in order to prevent the renmenbi from appreciating too rapidly. This has helped in keeping Chinese exports competitive in the United States, and led to the recent creation of the China Investment Corporation.

The "Export Engine" economies seem to be the better strategy since it enhances external trade and engender favourable balance of trade and balance of payment, hence facilitates domestic economic growth by providing job for the citizenry and stimulate the real and productive sectors of the economy which may translate to visible improvement in the standard of living and other indexes of economic development. SWFs have shown that abnormal return of 802 acquisitions of stakes in public traded companies by 33 SWFs resulted in significant negative returns in the two year holding period following the investment. Again, it has been confirmed that the long-run performance of SWFs investments tend to be poor. Even so, the three year buy-and-hold return of SWFs investments of 7.2 percent indicates 
lower than the market return. This is consistent with imperfect portfolio diversification and poor corporate governance. Given these stark realities, the true beneficiaries of SWFs become questionable.

The investment pattern shows a particular trajectory, in that large share of SWF investment (about half of the total investment) went into financial sector, and it has been observed that US financial market received half of the fund. SWFs also injected large fraction investment in distressed US and European Investment Banks. This corroborates the thesis that SWFs essentially are instruments to salvage the distressed financial and real sectors of the Western capitalist economies, a task shied away from by domestic investors due to poor return on investments. An assertion agreed with by the DB Research that, the investments by the SWFs represent a source of capital in the recipient companies and economies as a whole which otherwise may not be available at all or only at higher costs. Hence, SWFs create and secure highly paid jobs in the Western Economies at the expense of the home states which may be boggling for finance and jobs using Nigeria as a good case study.

Ironically, the Western Nations cynically, raised concern over the SWFs despite the inherent benefit to the economies. This is because there is lack of transparency, and their size has the potential to disrupt financial markets, with the attendant risk of infused political objectives intended to influence their management. There is very high suspicion because of the secretiveness and closed shop management style. In essence, the SWFs could buy up assets across the world without other investors knowing what they are doing. This therefore underlines the lack of trust, uncertainty and volatility of the financial markets already struggling to understand investments by private equity, hedge funds and other new actors.

Amazingly, secrecy is not only the hallmark of such funds as Central Banks across the globe are also guilty of this. In reality, it is citizens of unaccountable paternalistic regimes who stand to lose most when rulers play games with their national wealth. The use of the funds for political leverage and source of obtaining strategic intelligence information from receiving state remains a thorny issue. If Sovereign Wealth Funds are extension of the state, then they may profit from exploiting other organs of the state-intelligence agencies, Central Banks, justice ministries etc. to gain unfair advantage in acquiring assets, and tilt the playing field in merger and acquisition of strategic assets as Dubai Port World acquisition of the port facilities in the United States and the CNOOC's attempt to acquire Unocal. The result is that the investment vehicles can give undue advantage to 'national champions' in the global market.

It must be understood that the realist-dominated Western society always expresses these concerns from the real politic perspective and argues that past evidence of good behaviour is no guarantee of future good behavior, given that who knows what the governments of countries such as China, Russia and Saudi Arabia may look like a decade from now, and what their political motivations might be?

These Phobia led the OECD and G7 to seek refuge in the International Monetary Fund, and World Bank, their instruments of Global Financial Governance for the fabrication 
of regimes capable of caging the operators of the Sovereign Wealth Funds (Badian \& Harrington, 2008).

Truman (2007) articulated the need for regulating the SWFs, "The international investment activities of governments have achieved a sufficient scale and scope that a strong case can be made to establish internationally agreed standard to guide the management by governments of their cross-border investments" as their activities have raised "broad strategic issues for the international financial system" (Lowery, 2007). The IFIs were requested to devise a code for the SWFs themselves; the OECD was tasked to design best practices for recipient countries. The IMF code would only hurt feelings, the idea is politically stupid and the process political bullshit (Gao Xiging as quoted by Drezner, 2008), was the summary of the SWFs to the proposed framework.

There are some hiccups on the Sovereign Wealth Funds in the form of regulations, code of conduct or principles of operations or best practice. There should be limits placed on transparency, and restraints on regulations to create breathing space for operations, because it has been noted that complete transparency would raise more questions than answers. As Norwegian Finance Minister, Kristin Halverson, was purported to have said, you may not like us, but you need our money. Given the displeasure following the proposed code, the Secretary General of OECD Angel Gurria, warned the West about stringent regulations or codes that would unduly restrict the freedom of investment, otherwise it would be doing ourselves a disservice. Even so, she appeals that, sovereign Wealth Funds, should be welcomed since OECD markets are open for foreign investments, national security should not be a cover for protectionism. Again, the OECD countries have agreed to use the security argument with restraint in response to the above.

Eventually, the IMF proposed International Working Group (IWG) to draft a set of best practices which called for preexisting fund standards with focus on governance and institutional arrangements (Drezner, 2008). The outcome was the drafting of Generally Accepted Principles and Practice (GAPP) which left transparency as the remaining sticking point. The thorny issue to the funds owner is the involvement of the Breton Woods Institutions in the codification of rules governing their operations notwithstanding the existing laws in individual recipient countries which spelt out the rules and regulations governing investment in all sectors of the economies: "most economies already have in place effective rules to promote market efficiency and competition. Most importantly, in all countries foreign investment transactions and operation of foreign-owned enterprises are subject to existing antitrust, reporting, and corporate governance requirements as applies to any corporation operating in the respective jurisdiction" (DB Research: 14).

Again with their membership of the International Monetary Fund, governments with SWF are already committed to the stability of International Financial System, (Article 4.1, Articles of Agreement IMF) hence, there was no need for the fabrication of new code of conduct to cage the funds. 
All said, the SWFs are owned by countries outside the core of world economy, majorly commodities exporting countries for stabilization, sterilization, intergenerational and pension savings, which are available for investment in the core states. The volume and quantity are increasing by the day due to tacit encouragement by the Breton Woods Institution, because of their usefulness in reviving distressed companies in Europe and America. The returns on investment are generally lower than expected margin of the private investors and the "economic meltdown of lost five years has eroded much speculated profit on the funds. The recipient countries are hypocritical in forcing the World Bank and IMF to fabricate code of conduct for the funds, when individual countries have existing laws covering this subject. This is seen as further effort to arm-twist the owners of the funds and cajole them into perpetual dependency status, after all, it is known that forceful rules have been imposed overtime in International Politics. Notwithstanding, the most benefiting fund owner is China, who uses it to sterilize the economy, shield it from Dutch Disease, make her export cheaper and attractive to the United States due to the low exchange rate of her currency.

Nigeria's entrance to the fund may be in itself part of the bandwagon activities of globalization, and the lack of transparency in the fund management as complained by the recipient countries, makes it more worrisome for a country whose officials are known for legendary corruption. Her experience in state capitalism may as well be decisive as discussed in the next section.

\section{An Overview of State Capitalism}

State capitalism is said to be the state involvement in the production and distribution of goods and services. It is the utilization of social assets by the government or its agencies in the productive sector of the economy. This is in contrast with the Liberal Economic model where states are expected to regulate and produce enabling environment for private individuals to engage in these activities. The emphasis should be on the development of productive forces, and in connection with it, the transformation of the disarticulated economic structure and the creation of an organic and more coherent integrated national economy. In other words, it entails reduction of the dependence of the native capitalist on foreign monopoly capital, and thus a corresponding measure of liberation from the domination of imperialism. It could also be seen as the state acting as a capitalist, when it uses government controlled funds to acquire strategic assets. We can also say that the principal actors of state capitalism are national oil corporations, state-owned enterprises, privately owned national Champions and SWF.

The emergence of State or National Oil Corporation; an engine room of state capitalism could be traced to the paradigm shift in the late $20^{\text {th }}$ century when the host governments of Multi-national Oil Companies, MNOCs, resented the domination and exploitation of their 
resources in line with the dictates of the colonial rules, vesting the ownership of the resources in the hands of the foreign companies and the requirement of unrealistic compensation, if the host states dare to take over. This lopsided regime was addressed through series of the United Nations General Assembly Resolutions:

(a) Resolution No 626 (VII) dated December 21, 1952 assented to "the right of peoples freely to use and exploit their natural wealth and resources is inherent of their sovereignty".

(b) Resolution No 1803 (XVII) dated December 14, 1962, titled Permanent Sovereignty Over National Resources, called for "The right of peoples and nations to permanent sovereignty over their natural wealth and resources must be exercised in the interests of their national development and of the well-being of the people of the state concerned".

(c) Resolution No 2158 (XXI) of 1966 acknowledges the General Assembly Position that: "Taking into account the fact that foreign capital, whether public or private, forthcoming at the request of the developing countries can play an important role in as much as it supplements the efforts undertaken by them in the exploitation and development of their natural resources, provided that there is government supervision over the activity of the foreign capital to ensure that it is used in the interest of national development.

- $\quad$ Recognizes the right of all countries, and in particular the developing countries to secure and increase their share in the administration of enterprises which are fully or partially operated by foreign capital and have greater share in the advantages and profits derived there from on an equitable basis, with due regard to development needs and objectives of the peoples concerned.

- Considers that, when natural resources of the developing countries are exploited by foreign investors, the later should undertake proper and accelerated training of national personnel at all levels and in all fields connected to exploitation.

(d) Resolution No 3281 (XXIX) dated December 12, 1974, titled "Charter of Economic Rights and Duties of States" provides that "Every state has and shall freely exercise full permanent sovereignty, including possession, use and disposal, overall of its wealth, natural resources and economic activities".

These resolutions effectively concretized the shift from the traditional concepts of investor ownership where individual rights, were emphasized towards host state ownership of natural resources. However, the Oil Producing and Exporting Countries OPEC, played a key role in the establishment of national oil companies in its member countries. The establishment of the Nigerian National Oil Corporation was a direct response to OPEC's call for member countries to establish national oil companies (NOCs) which would be vehicles for state participation in the oil industry. Its resolution of 1970 requires member countries to obtain at least 20 percent interests in existing concessions. In addition, the UN Resolution 2158 of 1966 was reasserted by Group 77 as the basis for renegotiating commodity agreements between Third World producer states and transnational corporation. 


\section{State Capitalism: The Nigerian Experience}

In 1971, Nigeria joined the Organization of Petroleum Exporting Countries (OPEC). In line with OPEC policies, Nigeria began to institute measures to take effective control of the oil and gas within its borders. More profound was the establishment of the Nigerian National Oil Corporation by Decree No 18 of 1971 in compliance with the Organization's Resolution XVI, Article 90 of June, 1968 which enjoined all member countries to acquire participating interest in the operations of the oil companies operating in their territories.

This development, cumulating to the taking over of the Port Harcourt Refinery from Shell British Petroleum was historical and contrasts the governmental lamentation of few years earlier. The petroleum industry is vital in any discussion of the Nigerian economy. It is sad that the activities of the oil prospecting and producing companies are shrouded in secrecy, and there has only been a scanty and general discussion around it. The industry is virtually private, except for government's partial interest in the refining branch. The Nigerian National Oil Corporation was responsible for managing government assets in upstream and downstream sector of the industry as the government was ready to play an important role in the exploration and exploitation of the country's natural resources. In other words, The Nigerian National Oil Corporation was established as an integrated oil company to explore, produce, process, transport, refine, distribute and market crude petroleum and its refined products. It was formed to carry out government's policies and to ensure government effective participation in the oil industry.

Consequently, government acquisition of participating interest in the foreign oil firms flourished, and by 1974, the Nigerian Enterprises Promotion Decree strengthened the state effort as at least $55 \%$ interest of each of the companies operating within its borders were in favour of the government. The National Oil Corporation operated in tandem with the Ministry of the Petroleum Resources which owns majority of the Petroleum Resources, which was majorly a regulatory agency and was not part of the state's instrument of participation. And the Nigerian National Petroleum Corporation was established in April, 1977 by the merger of the defunct Nigerian National Oil Corporation and the former Federal Ministry of Petroleum Resources. This was done in order to create a more virile oil agency, and optimize the scarce human and infrastructural resources by Decree 33 and its functions were to combine the commercial objectives of NNOC antecedent (namely, exploration, production, transportation, refining, processing or, marketing of crude oil and products, as well as research) and the regulatory functions of the former Ministry of Petroleum Resources, to be exercised by Petroleum Inspectorate.

Nigeria, drawing from the experience of other oil producing countries like Indonesia who pioneered a production sharing arrangement followed suit with similar agreement with Ashland Oil Company; expected to put up necessary funds to explore, develop and produce oil on behalf of Nigerian government, their proceeds would be shared according to the agreed percentage. The government also increased its participation interest in the foreign oil 
companies in 1978-79 to $60 \%$ and nationalized all the British Petroleum interests in Shell BP. This increased her holding in Shell to $80 \%$ and $70 \%$ of total oil produced in the country. The partnership of the Nigerian oil giant and the foreign companies is the foundation of the Joint Venture Agreements (JVAs) which increased government earning from oil and, "formed part of the fiscal regime to promote competition and maximize investment along with memorandum of understanding ... which encompasses attractive incentives for joint venture partner to sustain and increase investment in exploration and production activities, which will increase the country's oil reserves and production" (Azaiki, 2007, p. 29-30).

The question is whether or not Nigeria has through the creation of the NNPC, wrested control of its petroleum resources. It is obvious that she has failed to meet its mission and goals since the NNPC has not been able to develop the human capabilities necessary to sustain effective management of upstream and downstream subsectors of the oil and gas industry. This is mainly because of institutional inadequacies and lack of an effective coordination in manpower development policy. In comparison, countries like Mexico and Algeria have state oil corporations which are fully capable of finding extracting oil, this is not the case for countries like Gabon, Nigeria, Saudi Arabia or the United Arab Emirates, due to the specific historical circumstances of each producer state, in particular, of the internal correlation of class forces and of its mode of integration into the world capitalist system. This is why Nigeria is merely a distributor state, encouraging a web of corruption and neo-patrimonialism, tamping the country into an extreme example of a weak comprador state, (Nore, 1982).

In retrospect, the establishment of the National Oil Corporation was more to satisfy the dictates of OPEC as comprador bureaucrats in the Ministry of Mines and Power were reluctant to release the lucrative oil sector to any other government agency. Turner (1982) observes that compradors in the oil ministry maintain ultimate control and prevent the pursuit of active government led technology transfer in the area of exploration and production. More so, state participation is only formal and of legal nature, and did not entail active state involvement in oil operations. These acquisitions were made smoothly. But gaining participation in the concessions of the established major through renegotiation was a more difficult step.

Evidently, the state subjects the ordering of exploration equipment such as rigs, boats, and logging, drilling or cementing equipment diving services and data computers for monitoring activities to the rigors of import licensing, while foreign companies which have devised ways of by-passing these stringent import regulations are contracted by the state to rent or sell these expensive exploration equipment to the NNPC. Shell, in particular engages in this transaction, and what it sells, it charges interest on freight and transportation costs (Edogun, 1985). These contradictions have reduced the state's capacity to keep the oil moving in the event of deteriorating relations with the Anglo-Dutch concern. The technocrats who advocated and sought to bring about the transfer of technology for finding and producing oil were overridden by company-comprador alliances. 
Arguably, state capitalism in the Nigerian Oil Industry does not include long-term policy to produce oil rigs, measuring devices, pipe-lines, pumping stations, tankers or any other essential equipment for exploring and producing petroleum. These amongst others can make Nigeria a representative of a rent-receiving landowner, instead of a state capitalist (Nore, 1982); since state policy was reduced to the requirements of class interests and the perpetuation of foreign monopoly to maintain and reproduce these class interests (Edogun, 1985). State capitalism in Nigeria can only properly be appraised through the NNPC, because it is a reliable indicator of the state oil industry and the nation's economic wellbeing. The NNPC has failed to live up to its mission statement of being a commercial, international corporation engaged in oil and gas activities, utilizing skilled manpower and current technology. It has rather become a den of corruption and an instrument of self aggrandizement by the ruling class in collaboration with the foreign firms, therefore providing the objective conditions that are favourable to dependence, exploitation and underdevelopment of the Nigerian state (Edogun, 1985).

\section{Nigeria's Search for a Stable Economic Order}

The search for a stable economic order is not new in Nigeria but the strategies and regimes differ. Even the disastrous Structural Adjustment Programme (SAP) orchestrated by the Breton Woods Institutions was said to be a path to economic recovery and self reliance. Hence the entrance of Nigeria into the SWF is yet another signpost to economic stability as designed by the wisdom of the same Breton Woods Institutions, whose policy designs had been detrimental to Third World development and Nigeria in particular. Ordinarily, a stable economic order must ensure price stability, balance of payment equilibrium, employment equilibrium, foreign exchange stability, economic growth and development, as well as reduce inflation and impact positively on the lives of the citizenry.

Such order could only be generated within the internal milieu, through massive investment in the infrastructural facilities which would enhance the capacity of the real sector of the economy and enhance industrial growth. This internal environment is what is missing in Nigeria due to historical antecedence and the character of the ruling class as discussed under Nigerian State capitalism. Therefore, the creation of such internal milieu should be national imperative in the search for a stable economic order. It is advised that, countries with surplus funds should thread with caution and should address the needs of the economy first. Again, countries with poor unemployment and current account deficits should reflect deeply before venturing into SWFs. Such advice is timely for Nigeria with myriad of negative socioeconomic indexes, as well as struggling to meet with the Millennium Development Goals targets of 2015 .

Government's position on the fund is that it will accelerate infrastructural development. It has been argued that if the funds could be invested domestically in accordance with the country's macroeconomic policy framework, it could as well be funded directly from the excess reserve without creating panic. Common sense dictates that if one's bank savings 
yields 2-4 percent, one should not go in search of loans with interest rates of 7-15 per cent, as this would be tantamount to borrowing back one's own fund at premium cost. Ultimately this is a wrong method to solving unemployment, growth and development challenges.

Given the low and abnormal returns on investment and susceptibility of SWF to financial crisis seen as not mere fluctuation of fortunes, but permanent destruction of value, it has been observed that developing countries' enterprises in the developed markets are mere sharecroppers who stand a chance to gain only when it rains well in the developed market. As such SWFs can only reap significant financial returns in emerging nations when investment surplus funds benefit from removal of production bottlenecks at home.

Again the transparent saga as highlighted under the dynamics of SWF is also a thorny issue. As well, the security and political paranoid of the West or recipient countries of the fund must be of utmost interest to Nigeria, since it has a potential to trigger off diplomatic tensions with countries of destination of such investment funds. This is imperative considering the Libya and other Arab States experience in the persisting Arab Spring, as the Western economies decide who to support and finance using the states' fund at their disposal and can also embargo the withdrawal of such fund thereby denying the owner the right to her investment, since there is no permanent friend, but supremacy of interest. This indeed may suggest that it is safer to have the resources invested at home where governmental control, access and management is readily available and the multiplier effects visible in the lives of the citizenry. After all, it is projected that Nigeria needs to invest 34 trillion naira over four years if it was to meet the growth target of being among the top 20 economies in the world by 2020. Infrastructural deficit is also known to be one major disincentive to investors in the country and an impediment to economic growth, which needs to be addressed decisively through massive investment in the sector.

Management of the Nigerian Fund attracts major players at Wall Street in the bid to grab the portfolio. Wall Street Titans, Goldman Sachs, Morgan Stanley and JP Chase - are courting top government officials for the management of the fund, (This Day, 2011). The import is essentially the creation and sustenance of jobs in the developed economies, while reducing employment opportunities in Nigeria when the portfolio becomes operational. Expenses on the consultancy, technical and administrative services would have created jobs within Nigeria where millions of University graduates are still roaming the street searching for underpaid jobs. The suggestion of the Minister of Finance, Dr. Okonjo-Iweala that Nigerians would be given preference does not hold water, since Nigeria may not have experienced managers in the emerging regime; and is risky to employ the mediocre, given the level of investment. This of course clears the coast for hiring Western Financial gurus whose pay packages would be in line with the prevailing wage bills of the developed countries. Fitting this profile would be the titans as mentioned earlier.

On the other hand, state capitalism in the Nigerian oil sector is hampered more by the class interest inherent in a neocolonial economy, beneficial to the "Cabal" at the expense of the citizenry; but if well implemented could generate economic indexes visible on the 
masses, as experienced by Algeria and Iraq who had development oriented ruling classes (Nore, 1982), and which accounts for the success of this scheme in these countries. Nigeria can learn from them. Technology connected with the exploration and production phase is not however monopolized and unobtainable. Some OPEC member states have successfully separated out the various aspects of the technology 'package' and have indigenized the capacity to obtain, use and perhaps even generate aspect of the technology used in the extractive phases of the industry.

Undoubtedly, the reforming and unbundling of the state capitalism engine, the NNPC, could generate the desired order. To achieve the result of economic advancement, the petroleum industry must diligently pursue its programme of increased indigenization to raise local content from the present level. Investing in the training needs of this integrated industry world have been the priority of the Nigerian State, as oil companies deliberately avoid and resist the transfer of technical knowhow but rather accommodate nationalist sentiments by recruiting and training nationals for management positions. The majors, in particular the European firms, British Petroleum and Shell, do seek to minimize their losses by adapting to even foreseeing and guiding, social and political change which simultaneously encourage commitment by an indigenous stratum to the institutions and values of capitalism.

Experience has shown that Norway, Libya, Mexico and Brazil control almost 100\% of the industry through government owned oil corporations which have turned around the economies of these states. Therefore, the sector which earn the nation $95 \%$ of its income (UNEP, 2011), deserves to be properly engineered in an integrated manner instead of dancing to the tune of the economic imperialists bent on perpetual subjugation of Third World economies to their dictates and control, through egoistic policy advice; SWF being the latest. The rational for SWFs by some OPEC members was laid bare thirty years ago. It was observed that, many oil producing countries like Saudi Arabia and Kuwait use a large percentage of their oil revenues either for luxury imports or investments in property and treasury bonds in other countries. Unfortunately, this has not made any direct positive impact on social capital. They sustain the fear of the political consequences that may arise in the long run. This is because they need to import skilled manpower. Therefore, the fear of upsetting the political equilibrium in the future is not to their advantage. This clearly shows the disparities in the endogenous dynamics of these states when compared with Nigeria as well as the compelling imperative why Nigeria should not toe their path.

\section{Conclusion and Recommendations}

The explosion of SWF Regime has raised many questions yelling for answers as well as fears from home and the recipient countries of the funds. These issues were discussed in the paper, and of particular interest to Nigeria was the rationale behind Nigeria's entrance to the Regime, given the myriad of socioeconomic indexes rendering such strategy undesirable at this point in time. We analyzed state capitalism as an alternative economic strategy which 
produced profound results in Third World countries, but was hampered in Nigeria due to the internal class structure and the orientation of this class. Consequently, the failure of this class in the Nigerian State is not the failure of the strategy itself, therefore reforming the key sector of Nigerian State capitalism in line with the radical OPEC countries like Libya, Algeria and Iraq would generate more positive economic dynamics germane to a stable economic order, than SWF which is an instrument of the Western economies to revive distressed firms in their countries, so as to save jobs and maintain social stability in the volatile capitalist system prone to depression and its inherent ripples.

The key to stable Economic order therefore lies in the deliberate effort of the Nigerian State to acquire the technology and knowhow across the integrated oil industry so as to enhance its earnings from this sector and diversify the economy with the earnings to other sectors such as, agriculture, infrastructural development as well as industrialization, which would in the long run provide alternative sources of revenue to the state even when the oil-wells dried up. After all, China's productive sector has remained the engine room of growth and development as well as the source of its Wealth Fund which is strategically used to reduce the appreciation of her currency, such that her exports to United States are competitive. This generates further economic ripples at home, as jobs are provided secured and sustained. The sum of these is the positive indexes on China. Nigeria can borrow these strategies if she desires stable and prosperous economic order. For SWF is an aspect of state capitalism that favours the recipient destinations only, and except as practiced by China and other "export engine economies".

\section{References}

Azaiki, S. (2007). Oil, gas and life in Nigeria. Ibadan: Y-Book.

Badian, L., \& Harrington. (2008). The politics of sovereign wealth. The International Economy, (Winter), 52-82.

Drezner, D. (2007). All politics is global: Explaining international regulatory regimes. Princeton: Princeton University Press.

Drezner, D. (2010). Bric by bric: The emergent regime for sovereign wealth funds. In Alan Alexandroff (Ed.). Can the world be governed? Rising states, rising institutions. Washington: Brookings Institution Press.

Edogun, C. (1985). The structure of state capitalism in the Nigerian petroleum industry. In Ake, C. (Ed.). The political economy of Nigeria. London: Longman.

Hildebrand, P. (2007, December 16.). The challenge of sovereign wealth funds. International Centre for Monetary and Banking Studies. 
International Monetary Fund. (2008, February). Sovereign wealth funds: A work agenda. International Monetary Fund, Washington DC.

Jen, S. (2007, May 3). How big could sovereign wealth funds be by 2015? Morgan Stanley Research Global.

Kern, S. (2007, September 10). Sovereign wealth funds-State investments on the rise. Deutsche Bank Research.

Lowery, C. (2007, June 21). Remarks on sovereign wealth funds and the international financial system. San Francisco.

Lyons, G. (2007, July/August). State capitalism: The rise of sovereign wealth funds and economic security. The American Interest 3.

MDG. (2010). MDG Report 2010. Retrieved from www.mdgs.gov.ng. Tell Magazine Business Nigeria.

Nore, P. (1982). Oil and the state: A study of nationalization in the oil industry. In Nore, P., \& Turner, T. (Eds.). Oil and class struggle. London: Zed Press.

Randolph J. (2008, April). Sovereign wealth fund tracker. Global Insight.

Rozanor, A. (2005, November). Who holds the wealth of nations. Central Banking Journal 15.

Sen, S. (2011). Sovereign wealth funds: An examination of the rationale. American Review of Political Economy, June, 8(1).

Setser, B., \& Ziemba, R. (2007). Understanding the new financial superpower - The management of GCC official foreign assets. RGE Monitor, December.

This Day. (2011, October 26). Nigeria.

Truman E. (2007). Sovereign wealth funds: The need for greater transparency and accountability. Peterson Institute for International Economics Policy Brief 07-6, August.

Truman E. (2008). A blueprint for sovereign wealth fund best practices. Peterson Institute for International Economics Policy Brief PB08 3, April.

Turner T. (1982). Nigeria: Imperialism, oil technology and the comprador state. In Nore P., \& Turner, T. (Eds.). Oil and class struggle. London: Zed Press.

UNEP. (2011). UNEP report on environmental assessment of Ogoniland. 